\title{
Recent developments in immunotherapy of acute myeloid leukemia
}

\author{
Felix S. Lichtenegger ${ }^{1,2}$, Christina Krupka ${ }^{1,2}$, Sascha Haubner ${ }^{1,2}$, Thomas Köhnke ${ }^{1,2}$ and Marion Subklewe ${ }^{1,2,34^{*}}$
}

\begin{abstract}
The advent of new immunotherapeutic agents in clinical practice has revolutionized cancer treatment in the past decade, both in oncology and hematology. The transfer of the immunotherapeutic concepts to the treatment of acute myeloid leukemia (AML) is hampered by various characteristics of the disease, including non-leukemia-restricted target antigen expression profile, low endogenous immune responses, and intrinsic resistance mechanisms of the leukemic blasts against immune responses. However, considerable progress has been made in this field in the past few years. Within this manuscript, we review the recent developments and the current status of the five currently most prominent immunotherapeutic concepts: (1) antibody-drug conjugates, (2) T cell-recruiting antibody constructs, (3) chimeric antigen receptor (CAR) T cells, (4) checkpoint inhibitors, and (5) dendritic cell vaccination. We focus on the clinical data that has been published so far, both for newly diagnosed and refractory/relapsed AML, but omitting immunotherapeutic concepts in conjunction with hematopoietic stem cell transplantation. Besides, we have included important clinical trials that are currently running or have recently been completed but are still lacking full publication of their results. While each of the concepts has its particular merits and inherent problems, the field of immunotherapy of AML seems to have taken some significant steps forward. Results of currently running trials will reveal the direction of further development including approaches combining two or more of these concepts.
\end{abstract}

Keywords: AML, Antibody therapy, Bispecific antibody, CAR T cell, Checkpoint inhibition, Dendritic cell vaccination, Epigenetic therapy, Immunotherapy

\section{Background}

Advances in immunotherapy have revolutionized cancer therapy in the past few years. Novel immunotherapeutic approaches are entering the mainstream of oncology. In hematology, progress has primarily been made in the field of B-lymphoproliferative diseases including acute lymphoblastic leukemia (ALL). In acute myeloid leukemia (AML), novel strategies utilizing the immune system to eliminate leukemic cells have only recently approached clinical application $[1,2]$. This is somewhat surprising, considering that allogeneic hematopoietic stem cell transplantation (HSCT) is one of the oldest immunotherapeutic strategies for postremission therapy in AML. So far, HSCT remains the most successful therapy for prevention of relapse in

\footnotetext{
* Correspondence: Marion.Subklewe@med.uni-muenchen.de

${ }^{1}$ Department of Medicine III, University Hospital, LMU Munich, Germany

${ }^{2}$ Laboratory of Translational Cancer Immunology, Gene Center, Munich, Germany

Full list of author information is available at the end of the article
}

non-favorable risk patients with AML [3, 4]. However, relapse after allogeneic HSCT does occur, and the vast majority of elderly patients are not eligible for HSCT. Therefore, alternative immunotherapeutic strategies are urgently needed to treat patients not suitable for intensive treatment regimens as well as patients with relapsed or refractory $(\mathrm{r} / \mathrm{r})$ disease [5].

In ALL, several antibody-based approaches have already entered standard treatment or are at the verge of approval. Rituximab, an anti-CD20 directed antibody has been shown to be beneficial as an additive to conventional chemotherapeutic agents [6]. Inotuzumab ozogamicin is a toxin-conjugated monoclonal antibody directed against CD22 on the surface of B cells. Approval in r/r ALL is expected in the next year after a phase III trial demonstrated $80.7 \%$ overall response rate (ORR) [7]. Moreover, novel T cell-recruiting therapies have opened up an entirely new approach to the treatment of acute leukemias, bypassing typical tumor resistance mechanisms [8]. Blinatumomab, 
a bispecific molecule connecting CD3 in the T cell receptor complex with CD19 expressed by B cells, was the first $\mathrm{T}$ cell-recruiting antibody approved for the treatment of cancer in 2014 [9]. Chimeric antigen receptor (CAR) $\mathrm{T}$ cells advance this concept even further by engineering a $\mathrm{T}$ cell with the specificity of a monoclonal antibody and a $\mathrm{T}$ cell activation domain. The engineered $\mathrm{T}$ cells are thus capable of targeting surface molecules of tumor cells in their native conformation independently of MHC [10]. In principle, all of these treatment modalities can be translated to AML.

However, targeted immunotherapy relies on a suitable target antigen to avoid unwanted on-target off-tumor toxicity. In ALL, the restricted expression profile of CD19 and CD20 allows to target these B cell-associated antigens. In AML, it is more difficult to choose an appropriate target antigen due to a more ubiquitous expression pattern overlapping with healthy hematopoiesis. Various potential target antigens are studied for each of the immunotherapeutic strategies [11, 12]. Still, it is to be expected that targeting AML-associated antigens will result in prolonged drug-induced cytopenias. This will require the adjustment of current protocols applied in ALL to the different setting in AML.

Other immunotherapeutic concepts rely on the enhancement of endogenous or the priming of new immune responses. Checkpoint inhibitors have been successfully approved in several solid organ malignancies and are now entering the treatment of hematological diseases [13]. And therapeutic vaccines, particularly those based on dendritic cells (DCs), have been shown to reliably induce anti-leukemic immune responses. Combining these two strategies not only with each other but also with hypomethylating agents (HMAs), which have been shown to modulate the immune function, seems suitable.

In this review, we will present recent advances made in the aforementioned fields of immunotherapy of AML. HSCT and immunotherapeutic strategies for relapse after HSCT constitute a review topic on their own and have been excluded. As published data from clinical trials is still scarce for the majority of immunotherapeutic approaches, we will integrate currently running clinical trials to point out upcoming directions in this field.

\section{Antibody-drug conjugates for immunotherapy of AML}

Compared to conventional antibody formats (Fig. 1a), antibody-drug conjugates (ADCs), consisting of monoclonal antibodies conjugated to various toxins, are a tool to bridge conventional chemotherapy and innovative immunotherapy. Upon internalization, the toxin is released in the acidic environment of the lysosomes and reaches the nucleus where it induces cell death through mechanisms like DNA double strand break and cell cycle arrest (Fig. 1b). The prerequisite for successful immunochemotherapy is a rapidly internalizing target antigen, preferably specific to the tumor [14].

CD33 (SIGLEC-3) is the antigen that has been most commonly targeted so far in AML. The first and most prominent $\mathrm{ADC}$ in clinical application was gemtuzumab ozogamicin (GO, Mylotarg, Pfizer), a humanized antiCD33 IgG4 antibody conjugated to calicheamicin. Promising clinical results lead to an accelerated approval of the antibody by the Food and Drug Administration (FDA) in 2000 [15]. Safety concerns and failure to verify clinical benefit in a confirmatory phase III trial enrolling patients across all cytogenetic risk groups resulted in the voluntary withdrawal of GO from the market in 2010 [16]. In recent years, both retrospective analyses and new clinical trials have been performed to unravel clinical benefits of GO in specific subgroups. A metaanalysis of five randomized controlled trials (RCTs) showed that the addition of GO to conventional chemotherapy significantly reduced the risk of relapse and resulted in an overall survival (OS) benefit mainly for cytogenetically favorable as well as for the intermediaterisk group [17]. Another meta-analysis of $11 \mathrm{RCTs}$ with one arm including GO showed improval in OS only for patients with favorable genetics [18]. A recent clinical trial testing GO vs. best supportive care including hydroxyurea in older patients with newly diagnosed AML unsuitable for intensive chemotherapy confirmed the clinical benefit, particularly in those patients with favorable or intermediate cytogenetic risk profile [19].

In order to further improve the clinical results with GO, several clinical trials have been performed evaluating GO in combination with HMAs. A regimen consisting of hydroxyurea, azacitidine, and GO was tested in a phase II trial for 142 older patients with newly diagnosed AML. The predefined goals concerning efficacy and safety were met for the poor-risk cohort (age $\geq 70$ years and performance status 2 or 3), but not for the goodrisk group [20]. GO in combination with both the histone deacetylase inhibitor vorinostat and the DNA methyltransferase I inhibitor azacitidine was studied in a phase I/II trial for older patients with $\mathrm{r} / \mathrm{r}$ AML. An ORR of $41.9 \%$ was seen among the 43 patients that were treated at the maximum tolerated dose, which can be considered rather high in this difficultto-treat cohort [21]. And finally, 110 patients with newly diagnosed or $\mathrm{r} / \mathrm{r}$ AML or high-risk myelodysplastic syndrome (MDS) were treated with decitabine and GO within a phase II study. Compared to historical controls, ORR was increased, but not OS [22]. Another combination trial with $\mathrm{GO}$ and azacitidine for patients with relapsed AML has not yet been reported (NCT00766116, Table 1). 

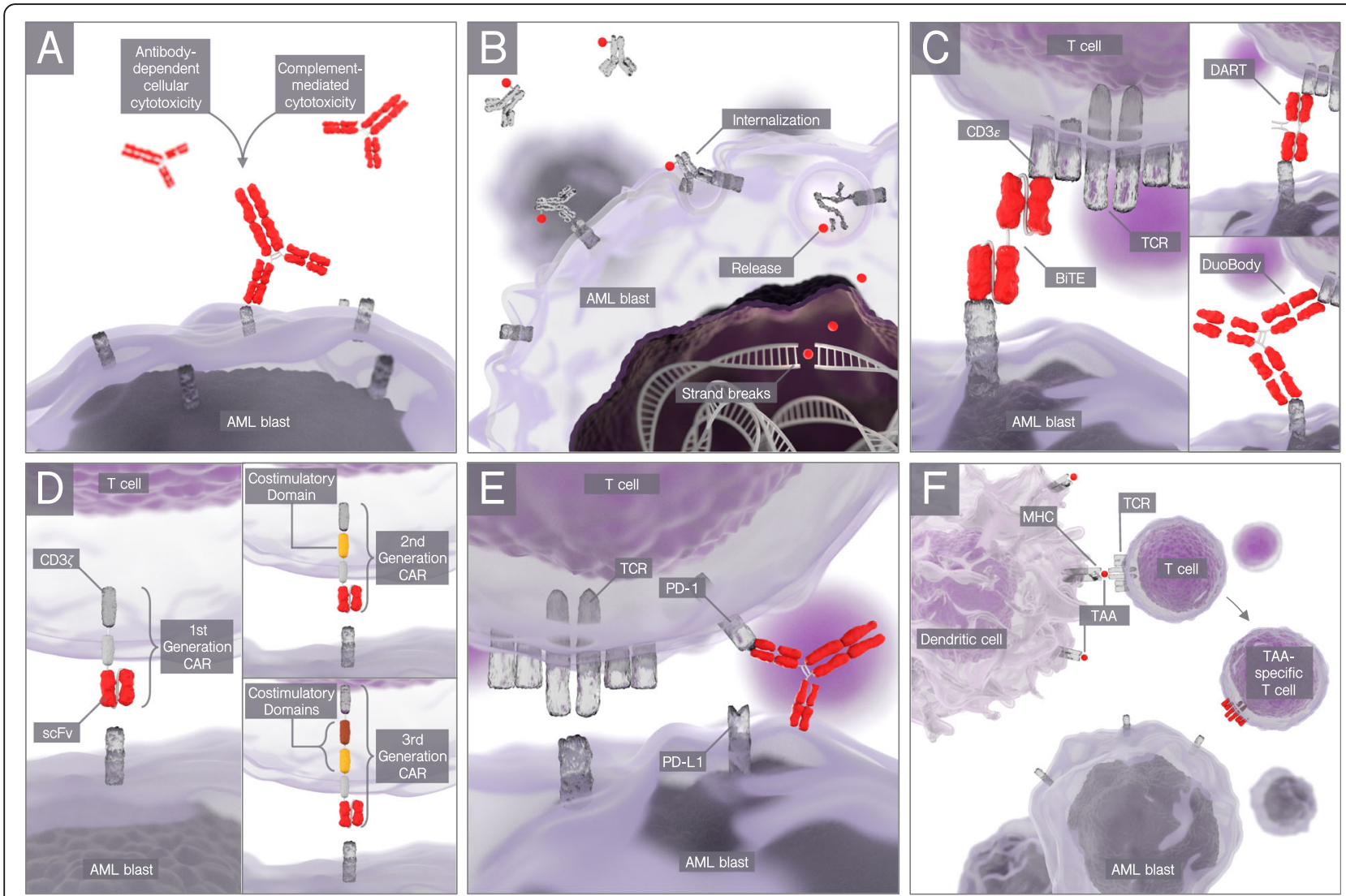

Fig. 1 Mechanisms of cancer immunotherapy. Different immunotherapeutic concepts are discussed in the context of AML in this review. a Conventional antibodies directed at AML surface antigens mediate antibody-dependent cellular cytotoxicity as well as complement-mediated cytotoxicity. b Antibody-drug conjugates consist of monoclonal antibodies conjugated to various toxins, which are released upon internalization and induce cell death through mechanisms like DNA double-strand break and cell cycle arrest. c T cell-recruiting antibody constructs are composed of single-chain variable fragments of two antibodies of different specificity connected by a short peptide linker. Their purpose is to bring malignant cells and T cells in close proximity through simultaneous binding of a tumor-associated antigen and CD3E in the T cell receptor complex. $\mathbf{d}$ Chimeric antigen receptors (CARs) are genetically engineered cell membrane-bound receptors combining extracellular antibody binding and intracellular effector cell signaling. Their structure enables both MHC-independent antigen binding and highly potent cytotoxic effector cell function. Compared to the first generation of CARs, the introduction of various costimulatory domains in later-generation CAR constructs greatly improved their anti-tumor effector function. e Checkpoint inhibitors are monoclonal antibodies binding to inhibitory receptors on T cells or their ligands on antigen-presenting cells or cancer cells, thus boosting the effects of pre-existing T cell responses. $\mathbf{f}$ Dendritic cells are professional antigen-presenting cells. Vaccination strategies using in vitro-generated dendritic cells have the purpose to prime new or enhance pre-existing antigen-specific immune responses

As CD33 is expressed on $>30 \%$ of healthy bone marrow cells, on-target off-leukemia toxicity is inevitable [23-25]. However, a major part of the side effects observed in the clinical trials with GO were attributed to linker instabilities and subsequent off-target toxicities $[26,27]$. A lot of effort has therefore been put into the optimization of the ADC technology. An alternative ADC directed against CD33, SGN-CD33A (vadastuximab talirine), has recently entered clinical trials. In this construct, a monoclonal anti-CD33 antibody is conjugated to a highly potent DNA-binding pyrrolobenzodiazepine dimer. The linker technology has been optimized and allows uniform drug loading [28]. Based on promising preclinical data, several clinical trials have been initiated evaluating safety and efficacy of SGN-CD33A alone or in various combinations. Twenty-seven treatment-naive AML patients ineligible for intensive chemotherapy were treated with the recommended monotherapy dose of $40 \mu \mathrm{g} / \mathrm{kg}$ within a phase I study (NCT01902329). The adverse events (AEs) observed were reported to be generally manageable, with a preponderance of myelosuppression. Combined complete remission (CR) and complete remission with incomplete recovery $(\mathrm{CRi})$ rate was $54 \%$ [29]. Within another cohort of the same study, 53 patients were treated with a combination of SGN-CD33A and HMAs, resulting in an encouraging CR/CRi rate of $73 \%$ [30]. The addition of the ADC to standard $7+3$ induction chemotherapy is tested within a large phase $\mathrm{Ib}$ 


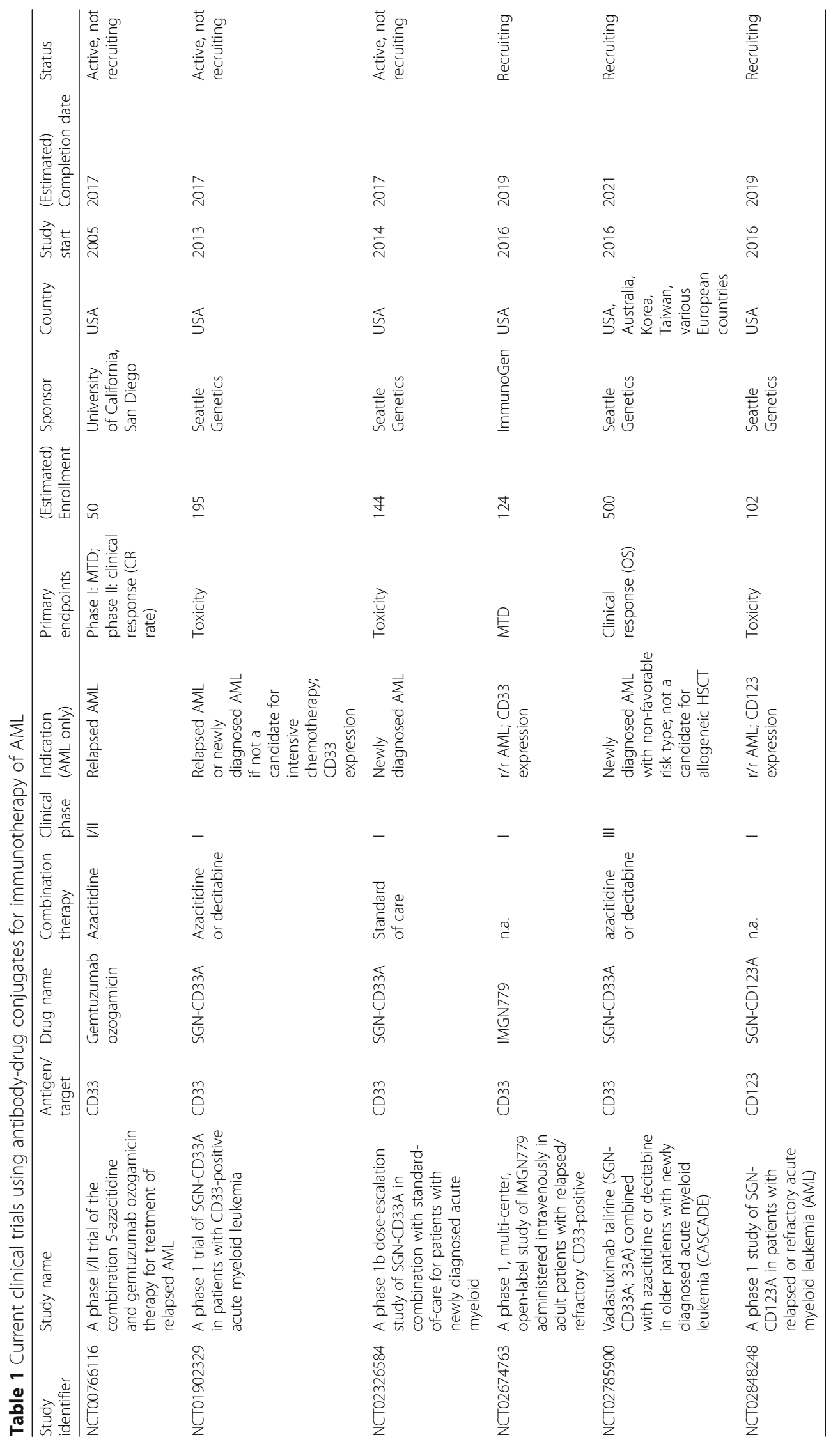


(NCT02326584) study. Preliminary results have been reported for the first 42 patients of this study. The combination therapy resulted in grade 4 myelosuppression in all patients, but no increase in non-hematological AEs was reported compared to chemotherapy alone. Synergistic effects of HMAs and CD33-directed immunotherapy are supported by a high CR/CRi rate of $78 \%$ [31]. This could be due to HMA-induced increase in CD33 expression as well as increased sensitivity to toxin-induced DNA damage [28]. Based on the encouraging response data, a phase III study of SGN-CD33A in combination with azacitidine or decitabine for older patients with newly diagnosed AML (CASCADE study) has recently been initiated (NCT02785900). However, potential hepatotoxicity, including veno-occlusive disease (VOD), is a major concern, particularly in the combination of SGN-CD33A with allogeneic HSCT before or after the treatment. Both phase I studies discussed above have therefore been put on hold by the FDA to explore the incidence of VOD, while the CASCADE trial continues enrollment [32].

SGN-CD123A is a similar ADC with the antibody directed at CD123 instead of CD33. CD123 is more restrictively expressed in the healthy hematopoietic compartment, which might decrease on-target off-leukemia toxicities $[24,33]$. This is being tested in the recently initiated phase I trial, which is planned to recruit $102 \mathrm{pa}$ tients with $\mathrm{r} / \mathrm{r}$ AML (NCT02848248).

ImmunoGen developed IMGN779, a CD33-directed monoclonal antibody conjugated to the novel DNAalkylating molecule DGN462. Preclinical data demonstrated highly specific in vitro and in vivo cytotoxicity against primary AML cells, especially in samples with an FLT-ITD mutation [34, 35]. The combinatorial approach of IMGN779 with the PARP inhibitor Olaparib resulted in enhanced ex vivo activity and a decreased tumor burden in a xenograft mouse model [36]. A clinical phase I study in $\mathrm{r} / \mathrm{r}$ AML is currently recruiting patients (124 patients planned, NCT02674763). Results of this study will show if there is any benefit over the usage of SGNCD33A in terms of the risk-benefit ratio. Apart from the conjugation to toxins, monoclonal anti-CD33 antibodies have also been conjugated to radioisotopes. However, first clinical studies have demonstrated less promising results and most of these strategies are currently not further pursued $[37,38]$.

Taken together, the field of ADCs finally seems to recover from the huge setback it originally suffered after the voluntary withdrawal of GO in 2010. A lot of effort has been put into the optimization of the ADC technology, and clinical results from early trials demonstrate promising response rates. Results of randomized phase III trials are eagerly awaited in order to estimate the risk-benefit ratio between a potential increase in response rates and the discussed side effects due to on- target off-leukemia toxicities and toxin-induced hepatic toxicity. In order to increase target cell specificity of the therapy, alternative target antigens are being evaluated in preclinical (i.e., CLL-1, SAIL) [39-41] and early clinical studies (i.e., CD25, FLT3) [42, 43].

\section{T cell-recruiting antibody constructs for immunotherapy of AML}

T cell-recruiting antibody constructs are a novel class of molecules composed of the single-chain variable fragments (scFv) of two antibodies of different specificity connected by a short peptide linker (Fig. 1c). Through simultaneous binding of a tumor-associated antigen and $\mathrm{CD} 3 \varepsilon$ in the $\mathrm{T}$ cell receptor complex, these small adapter molecules bring malignant cells and $\mathrm{T}$ cells in close proximity. The binding of $\mathrm{CD} 3 \varepsilon$ leads to $\mathrm{T}$ cell activation and expansion resulting in Granzyme B/perforin-mediated target cell lysis. The special feature of this strategy is that virtually any memory $\mathrm{T}$ cell can be recruited for target cell lysis irrespective of its specificity [44, 45]. Clinical proof of concept has been provided with blinatumomab (BLINCYTO ${ }^{\circ}$, AMGEN), a CD19/CD3 T cellrecruiting antibody construct. It was approved as the first in its class by the FDA in 2014 for $\mathrm{r} / \mathrm{r} \mathrm{Ph}$ negative B-precursor ALL, after a clinical phase II trial demonstrated a CR/CRi rate of $43 \%$ after one or two cycles of therapy [9]. Very recently, the superiority of blinatumomab to conventional chemotherapy for patients with $r / r$ B-precusor ALL was proven in a randomized phase III trial [46].

In AML, several $\mathrm{T}$ cell-recruiting antibody constructs are under preclinical and early clinical development (Table 2). Similar to the ADCs, the optimal antigen to target is still an open question. The sister molecule of blinatumomab, AMG 330, is a bispecific T cell engager (BiTE) construct targeting CD33 [25, 47]. The high inter- as well as intra-patient variations in CD33 expression levels might influence the success of targeted immunotherapy. Significantly lower expression has been demonstrated for $\mathrm{CD} 34^{+} / \mathrm{CD} 38^{-}$leukemia-initiating cells (LICs) vs. AML bulk cells, but expression was still significantly higher compared to their healthy counterparts $\left(\mathrm{CD} 34^{+} / \mathrm{CD} 38^{-}\right.$normal hematopoietic stem cells). In preclinical studies, the preincubation of AML cells with AMG 330 and T cells prevented the subsequent engraftment of AML in NOD/SCID gamma null (NSG) mice. This suggests that the CD33 expression level of LICs is sufficient for elimination with $\mathrm{T}$ cell-recruiting constructs. Besides, it has been demonstrated in vitro that the CD33 expression level mainly influences kinetics of cytotoxicity, but not necessarily the response rate $[25,48]$. Recently, an international, multicenter phase I trial for $\mathrm{r} / \mathrm{r}$ AML patients $(n=50)$ was initiated (NCT02520427), but data are not yet available. Several 


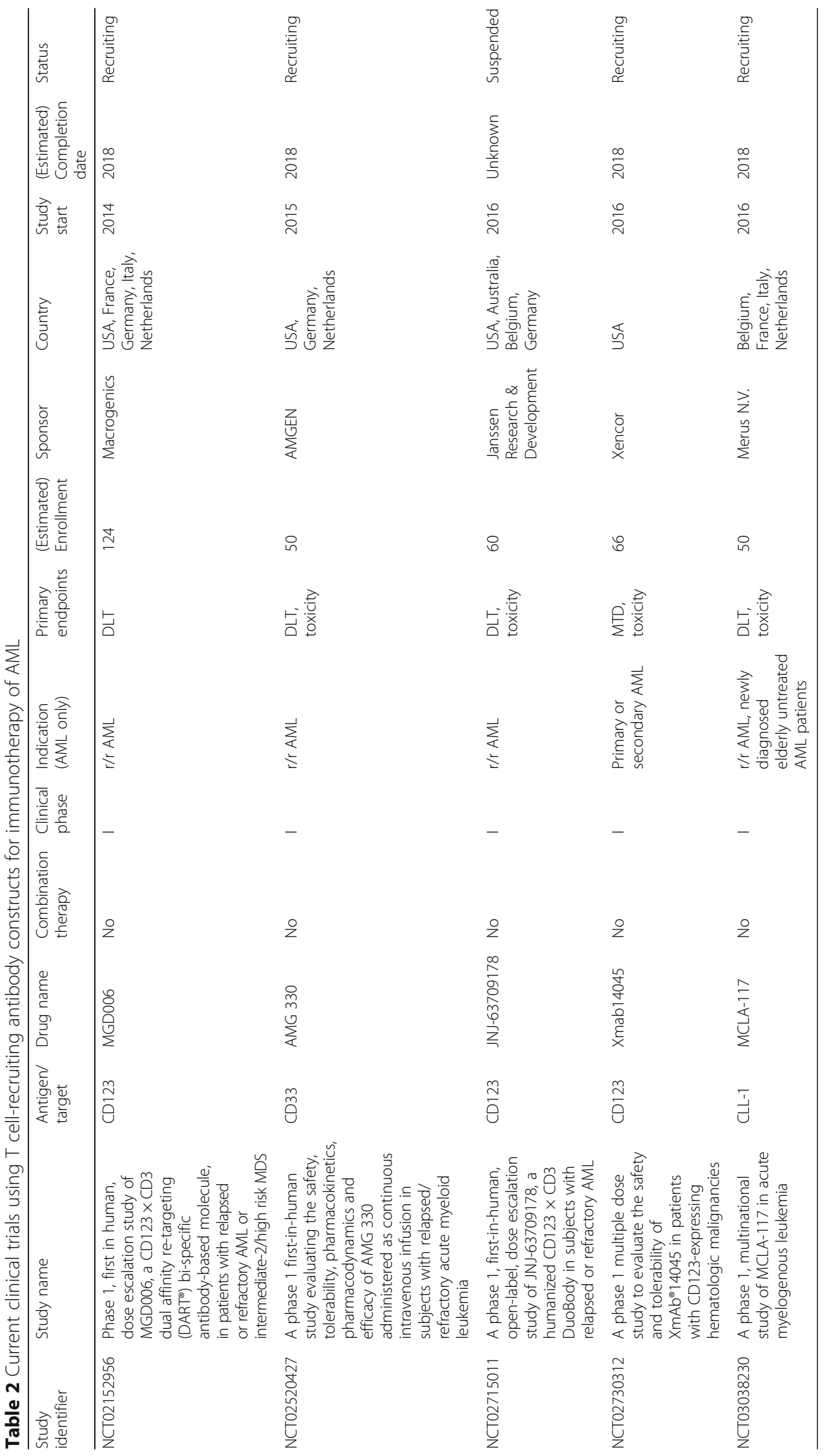


other CD33-targeting antibody constructs that differ from AMG 330 in their molecular structure are currently evaluated in preclinical settings $[12,49,50]$.

To reduce on-target off-leukemia toxicity, alternative AML-associated targets are being explored. CD123 has a lower level of expression on healthy hematopoietic cells compared to CD33 [24, 33]. Therefore, several T cellrecruiting antibody constructs targeting CD123 have been developed and are currently in early clinical studies. One of these constructs is MGD006, developed by MacroGenics. In contrast to the BiTE technology, dual-affinity re-targeting (DART) molecules are composed of heavy and light chain variable domains of two antigen-binding specificities $(\mathrm{A}+\mathrm{B})$ on two independent polypeptide chains $\left(\mathrm{VL}_{\mathrm{A}}-\mathrm{VH}_{\mathrm{B}}-\mathrm{VL}_{\mathrm{B}}-\mathrm{VH}_{\mathrm{A}}\right)$, which are stabilized through an additional C-terminal bridge [51, 52]. Encouraging preclinical data in terms of cytotoxicity against primary AML cells [53] and safe and well-tolerated infusion of MGD006 in cynomolgus monkeys [54] paved the way for the clinical development in a multicenter phase I study of 124 relapsed/refractory AML patients (NCT02152956).

XmAb14045, developed by Xencor, is a structurally distinct anti-CD123 T cell-recruiting antibody construct in early clinical development. The XmAb technology ensures structural stability and an extended serum half-life through the retention of an inactive Fc part. Preclinical studies in cynomolgus monkeys showed rapid clearance of $\mathrm{CD}_{123^{+}}$cells from the bone marrow as well as from the periphery [55]. These studies formed the basis for the initiation of a clinical phase I study for the evaluation of safety and tolerability of Xmab14045 in 66 patients with CD123-expressing hematological malignancies including primary and secondary AML (NCT02730312).

JNJ-63709178, a CD123/CD3 humanized IgG4 antibody has been developed by Genmab using their DuoBody technology. Preclinical studies in vitro and in vivo showed highly specific $\mathrm{T}$ cell activation and targeting of primary AML cells $[56,57]$, which lead to the initiation of a phase I study in relapsed/refractory AML $(n=60$, NCT02715011). Currently, the study is on hold because of the occurrence of undisclosed adverse events.

CLL-1 is a novel target antigen in AML characterized by its high expression on AML bulk cells as well as LICs $[58,59]$. Recently, a bispecific CLL-1/CD3 antibody construct (MCLA-117) has been developed by Merus B.V. MCLA-117 induced target antigen-specific cytotoxicity against primary AML cells at low E:T ratios using either allogeneic or autologous T cells. This led to the initiation of a clinical phase I trial in $\mathrm{r} / \mathrm{r}$ or elderly, previously untreated AML patients (NCT03038230, $n=50$ ) [60].

Results of the ongoing trials are awaited to see if the success in ALL will translate into the setting of AML. A potential future strategy could be to use the evolving antibody technology to simultaneously target two different
AML-associated antigens in order to increase specificity [61]. Apart from that, lots of effort has been put into optimization of the antibody technology to increase safety. The Probody ${ }^{\mathrm{Tm}}$ technology by CytomX uses antigenbinding site masking peptides attached to antibody constructs by substrate-cleavable linkers. In the tumor microenvironment, linkers are cleaved by highly active proteases generating effective immunotherapeutic agents directly at the tumor site [62]. Recently, an EGFR/CD3 Probody $^{\text {mix }}$ has shown promising results in terms of efficacy and increase in therapeutic window in preclinical studies in vitro and in vivo. As the technology relies on tumor site-specific protease activity, it remains to be determined if this approach is also feasible in acute leukemia [63].

Independently of considerations about the optimal target antigen, we are only at the beginning of understanding the exact mechanism of action of those antibody constructs and resistance mechanisms that potentially evolve upon $\mathrm{T}$ cell activation. Despite the promising response rate of $43 \%$ using blinatumomab in heavily pretreated ALL patients, reasons for resistance in the remaining patients have not been resolved. Only few biomarkers for response have been determined so far, e.g., in case of the blinatumomab studies, the percentage of blasts in the bone marrow and the degree of T cell expansion $[9,64]$. PD-L1 upregulation on AML cells upon $\mathrm{T}$ cell activation has been suggested as a potential resistance mechanism in an ex vivo system [48] and in a case report of a blinatumomab-refractory B-precursor ALL patient [65]. Addition of a checkpoint inhibitor to T cellrecruiting antibodies might help to circumvent resistance. A clinical study testing this concept by addition of an anti-PD1 antibody with or without an anti-CTLA4 antibody to blinatumomab for the treatment of $r / r$ ALL patients has been initiated, but is not yet open for patient recruitment (NCT02879695).

\section{CAR T cells for immunotherapy of AML}

Circumventing $\mathrm{T}$ cell exhaustion, anergy and senescence, CAR $\mathrm{T}$ cells take the technology of $\mathrm{T}$ cellrecruiting antibody constructs one step further and have already shown promising clinical results in various hematologic malignancies. CARs are genetically engineered cell membrane-bound receptors that combine extracellular antibody binding and intracellular effector cell signaling, thereby enabling both MHCindependent antigen binding and highly potent cytotoxic effector cell function (Fig. 1d). Since the first generation of CARs in 1989 [66], the introduction of costimulatory domains (mainly CD28 or 4-1BB) in socalled second-generation CAR constructs greatly improved their anti-tumor effector function and paved their way into clinical trials [67]. 
To date, the most prominent target antigen for CAR T cell therapy is CD19, due to its restrictive expression pattern and good safety profile. Groundbreaking early clinical trial results could be achieved for various B cell malignancies. In $\mathrm{r} / \mathrm{r}$ B-ALL, treatment with anti-CD19 4-1BBcostimulatory CAR $\mathrm{T}$ cells achieved MRD-negative CR rates of $86 \%$ for 29 patients [68]. These are outstanding clinical results, considering the heavily pretreated patient population that was included: in the median, patients had received three prior intensive chemotherapy regimens, and more than one third had relapsed after prior allogeneic HSCT. In another recently published trial, treatment with anti-CD19 CD28-costimulatory CAR T cells showed great clinical efficacy with CR rates of $57 \%$ in seven patients with DLBCL refractory to at least three prior lines of therapy [69]. As of November 1, 2016, 1135 patients have been treated with anti-CD19 genetically engineered TCR/CAR T cells [70], leading to high expectations for patients with no therapeutic options until now. Accordingly, there are currently 87 open clinical phase I or II trials involving anti-CD19 CAR $\mathrm{T}$ cells in B cell malignancies (ClinicalTrials.gov, last update 03/07/2017).

Despite these promising early results and the rapidly expanding number of anti-CD19 CAR T cell trials, this novel drug format is still incompletely understood and cannot generally be considered safe. In March 2017, Juno announced to shut down development of antiCD19 CD28-costimulatory JCAR015 CAR T cells and to close their phase II ROCKET trial in $\mathrm{r} / \mathrm{r}$ adult ALL, after five treatment-related deaths had occurred due to CAR T cell-mediated neurotoxicity [71]. As "living drugs," the in vivo effect of CAR T cells may be dependent on different conditioning chemotherapy regimens, CAR $\mathrm{T}$ cell manufacturing protocols and costimulatory domains. Unfortunate combinations of these variables may promote rapid in vivo expansion of CAR $T$ cells with the potential to induce severe systemic and neurological side effects.

Translating CAR T cell therapy to AML is complicated again by the non-restricted expression of AMLassociated antigens. Given that current CAR T cell constructs can persist beyond 4 years in the human body [72], several strategies are being explored to circumvent unwanted on-target off-leukemia toxicity, particularly long-term myeloid cell aplasia. Similar to ADCs and T cell-recruiting antibody constructs, the identification of AML-specific target antigens or antigen combinations would be one way to improve safety of future CAR T cell approaches in AML. To date, several target antigens for AML CAR T cell therapy are under preclinical and clinical investigation.

CD33 is the most prominent target antigen for CAR T cells in preclinical trials due to its high and persistent expression in the majority of AML patients [24, 73]. In an in vivo model of AML-xenotransplanted NSG mice, treatment with anti-CD33 CAR T cells resulted in marked reduction of leukemic burden and prolonged survival [74]. However, significant on-target off-leukemia toxicity with reduction of myeloid lineage and hematopoietic stem cells was observed. In another in vivo model of AMLxenotransplantated NSG mice, treatment with only transient CAR expression via electroporation of $\mathrm{T}$ cells with anti-CD33 CAR-encoding RNA resulted in similar, but only transient cytotoxicity [75]. Application of CAR T cells directed against CD123 as an alternative target in an in vivo model with AML-xenotransplanted mice resulted in significant reduction of leukemic burden and prolonged survival with only limited on-target off-leukemia toxicity and unaffected healthy hematopoiesis [76-79]. In contrast, eradication of normal human myelopoiesis was demonstrated in another in vivo mouse study with anti-CD123 CAR T cells [80]. Interestingly, modifying the anti-CD123 scFv by utilizing $\mathrm{V}_{\mathrm{H}}$ and $\mathrm{V}_{\mathrm{L}}$ chains from different monoclonal antibodies could reduce myelotoxicity in an AML mouse model [79]. This conflicting data indicates that variations in antibody clone, costimulatory domain, effector cells, and model system might account for vastly different outcomes. Fine-tuning the development process of CAR T cells might be able to provide differential recognition of target antigens on leukemic vs. healthy cells.

Other potential target antigens identified in preclinical studies include CD44v6 [81], CLL1 [82], FLT3 [83], FR $\beta$ [84], LeY [85], NKG2D [86], and PR1/HLA-A2 [87].

To date, only one very small trial evaluating anti-LeY CAR T cells (CTX08-0002) in r/r AML has been completed. None of the four treated patients developed grade 3 or 4 toxicity, and infused CAR T cells persisted for up to 10 months. One patient with active leukemia responded with transient reduction in blast count before progression 1 month later. All patients relapsed 28 days to 23 months after adoptive CAR $\mathrm{T}$ cell transfer [88]. Currently, there are four open phase I clinical trials that evaluate the application of CAR constructs in $r / r$ AML (Table 3). One trial recruiting in China is including patients with $\mathrm{r} / \mathrm{r}$ AML for treatment with anti-CD33 CAR cytokine-induced killer (CIK) cells (NCT01864902). So far, there has only been a report of one patient within this trial who showed a transient decrease in blast count while suffering from cytokine release syndrome and pancytopenia [89]. Trial completion is estimated to be in 2017. Two other trials evaluate lentivirally transduced or mRNA-electroporated anti-CD123 CAR T cells, respectively (NCT02159495, NCT02623582), however, the latter one has been prematurely terminated. Until now, no results have been published. Another phase I trial utilizing allogeneic "off-the-shelf" anti-CD123 CAR T cells (UCART123) was recently opened (NCT03190278 [90]). And finally, a trial applying CAR $\mathrm{T}$ cells directed at 


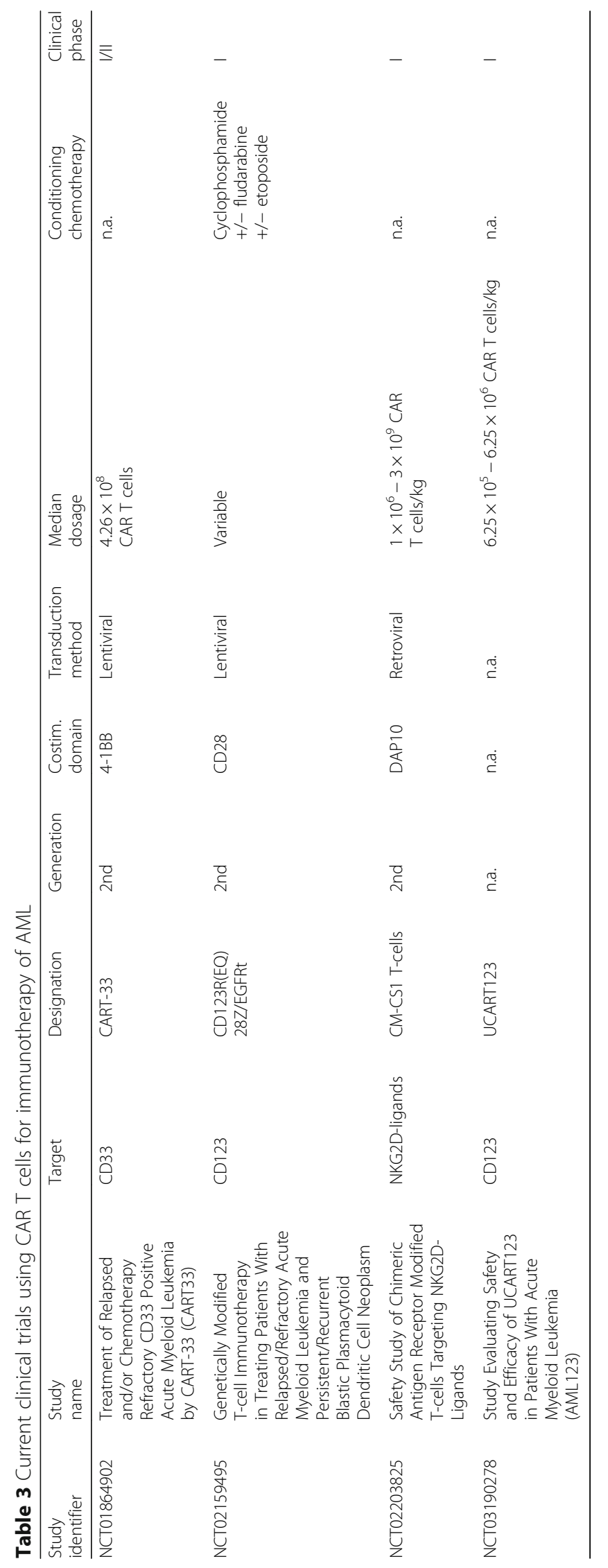




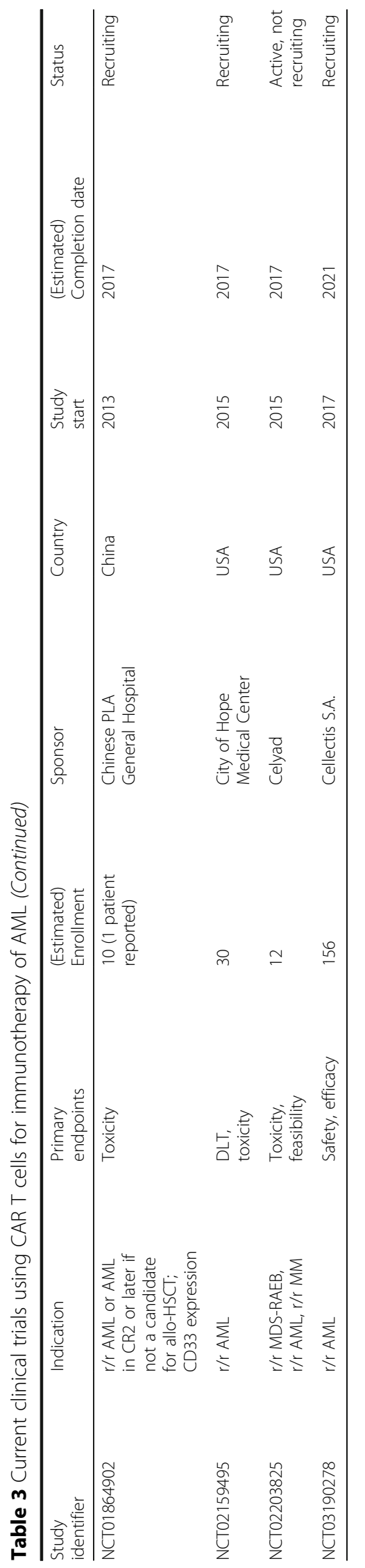


NKG2D ligands to patients with $\mathrm{r} / \mathrm{r}$ AML, MDS, and multiple myeloma is estimated to be completed in 2017, but results are still pending (NCT02203825).

Novel CAR designs are explored to increase the specificity and to improve safety profiles. In preclinical in vivo models, dual-targeting approaches targeting two independent leukemia-associated antigens were shown to provide increased specificity accompanied by reduced off-leukemia toxicity [91] and to prevent antigen escape mechanisms [92]. In vitro, it was demonstrated that dual targeting of CD33 and CD123 was superior to monospecific approaches in terms of specific cytotoxicity [93]. Further preclinical investigation and translation of dualtargeting strategies into clinics could contribute to efficacy and safety in CAR T cell therapy in AML where target specificity remains a major issue. On-target offleukemia toxicity could also be further reduced by finetuning of CAR density and CAR binding affinity [94]. In light of safety concerns due to unrestricted in vivo CAR $\mathrm{T}$ cell expansion and activation, methods of selective CAR $\mathrm{T}$ cell depletion are currently being investigated. Integration of so-called suicide gene systems into CAR constructs could act as safety switches enabling rapid on-demand elimination of CAR T cells that would otherwise turn uncontrollable. These suicide gene systems can be based on enzymatic activation of cytotoxic prodrugs, antibody-based targeting of overexpressed surface antigens, or pharmacological induction of apoptosis via inducible caspase 9 which is already tested in clinical phase I CAR T cell trials (NCT03016377 [95]).

\section{Checkpoint inhibitors for immunotherapy of AML}

In contrast to the immunotherapeutic concepts discussed so far, monoclonal antibodies against checkpoint molecules are applied with the idea to unleash pre-existing anti-tumor T cell responses (Fig. 1e). Within recent years, checkpoint inhibition has probably become the single biggest hype in cancer immunotherapy, primarily in solid oncology, but meanwhile, also finding its way into hematology [96]. Most prominently within hematologic diseases, anti-PD-1 antibodies show remarkable success in Hodgkin's lymphoma and are tested in various nonHodgkin lymphomas. However, there is growing evidence from in vitro experiments and murine models that this strategy could also be applied to AML [96].

Only one clinical study applying a checkpoint antibody as a monotherapy to AML patients has been published so far. Eighteen patients with various hematologic malignancies, including eight patients with AML, were treated with the anti-PD-1 antibody pidilizumab within a phase I study. The antibody was shown to be safe and well tolerable, and one of the AML patients showed a minimal response manifested by a decrease in peripheral blasts from 50 to 5\% [97]. A phase I study testing the CTLA-4 antibody ipilimumab in various malignancies including 12 patients with AML has long been completed, but to our knowledge, specific results for AML patients have not been published (NCT00039091, Table 4). Another phase I study, in which ipilimumab was applied to 54 patients with refractory AML, MDS, or chronic myelomonocytic leukemia (CMML), has finished recruiting, but results have not yet been reported (NCT01757639). And three phase II studies (NCT02275533, NCT02532231, NCT02708641) are studying the effect of PD-1 inhibition with either nivolumab or pembrolizumab as a monotherapy on prevention of relapse in remission.

While the results of these studies have to be awaited to judge the potential of checkpoint inhibitors as a monotherapy for AML, various combination therapies are already tested in clinical trials. A phase II study is combining lymphodepletion with a fludarabine/melphalane regimen followed by autologous stem cell transplantation with anti-PD-1 therapy with the goal to reduce relapse rates in non-favorable AML patients in remission (NCT02771197). The combination of standard high-dose cytarabine with anti-PD-1 therapy is tested as a salvage therapy in a phase II study planned to recruit 37 patients with $\mathrm{r} / \mathrm{r}$ AML (NCT02768792). And a phase I/II study analyzes the maximal tolerable dose of an anti-PD-1 antibody in addition to idarubicin and cytarabine for induction of de novo AML (NCT02464657). No results for any of these studies have been reported so far. The combination of a PD-1 antibody with a vaccination strategy based on AML DC hybridoma is described in the DC chapter below (NCT01096602, Table 5).

A high interest is currently generated by the idea to combine checkpoint inhibition with HMAs. The evaluation of PD-1 as well as PD-L1 expression in patients with MDS or AML receiving HMAs showed upregulation of both markers on mRNA level [98]. Therefore, several trials are evaluating the efficacy of HMAs combined with either CTLA-4, PD-1, or PD-L1 blocking antibodies (Table 4). First results for this strategy within a phase Ib/II study combining the PD-1 blocking antibody nivolumab with azacitidine in patients with $\mathrm{r} / \mathrm{r}$ AML have recently been presented. Toxicity was comparable with other trials using checkpoint blockade, and outcomes have been encouraging with a median overall survival of 9.3 months in this study with a predominantly poor-risk patient population [99].

Taken together, checkpoint inhibition in AML is still in its infancy, and results of the currently ongoing trials have to be awaited before further conclusions about the applicability of this concept to AML and the existence of any AML-specific side effects of checkpoint inhibition can be drawn. Combination therapies including checkpoint inhibitors, particularly with HMAs, might turn out to be an important step forward. 


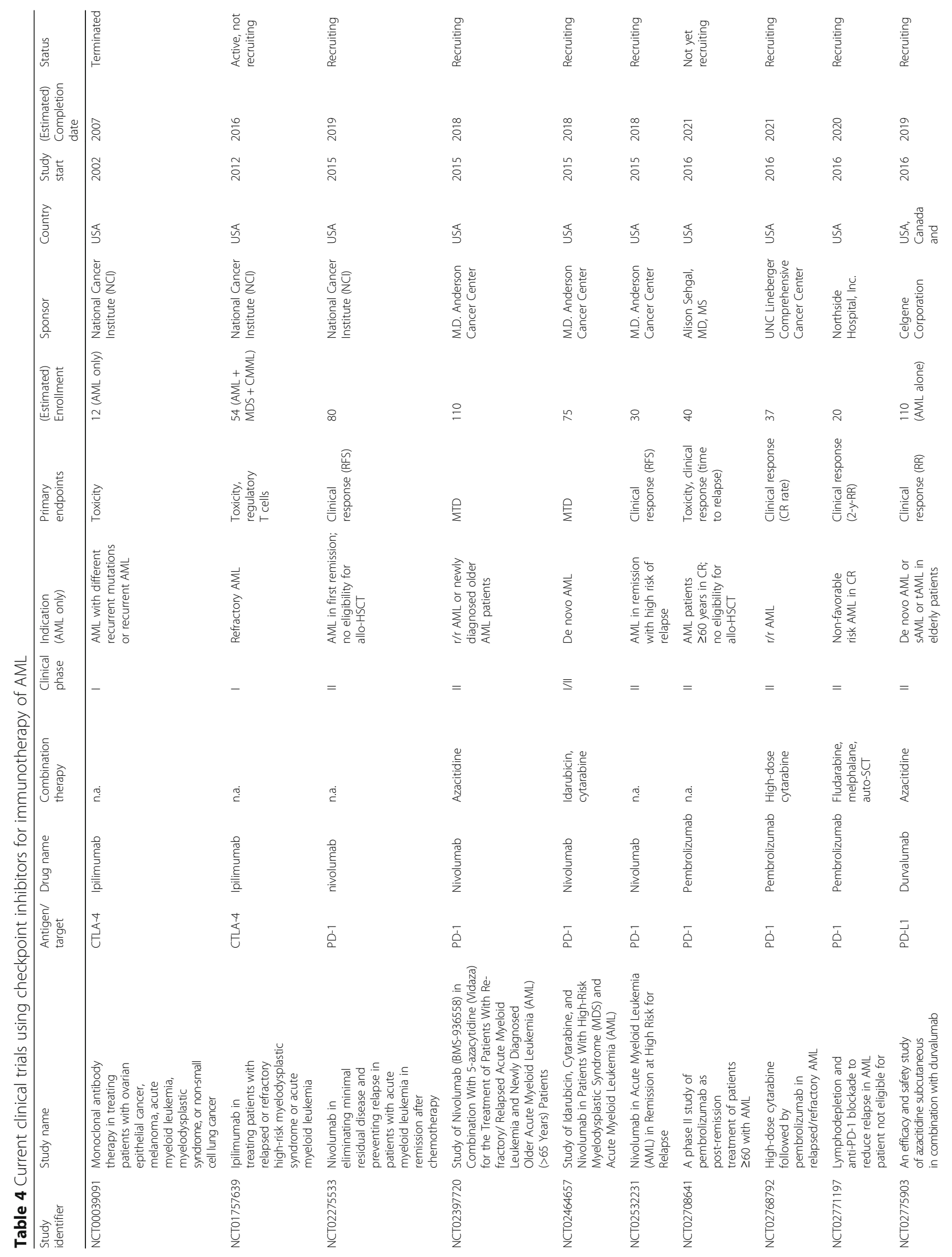




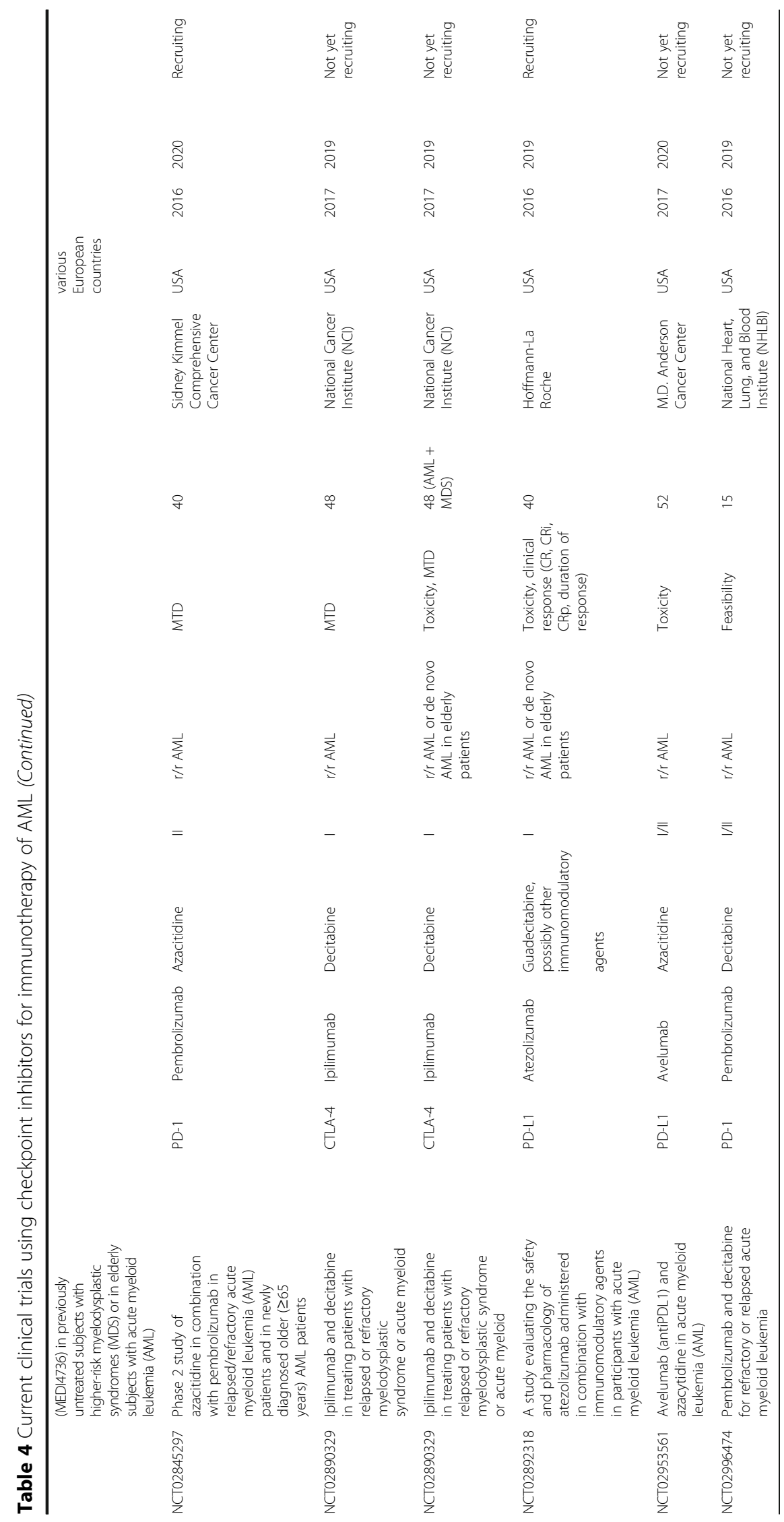




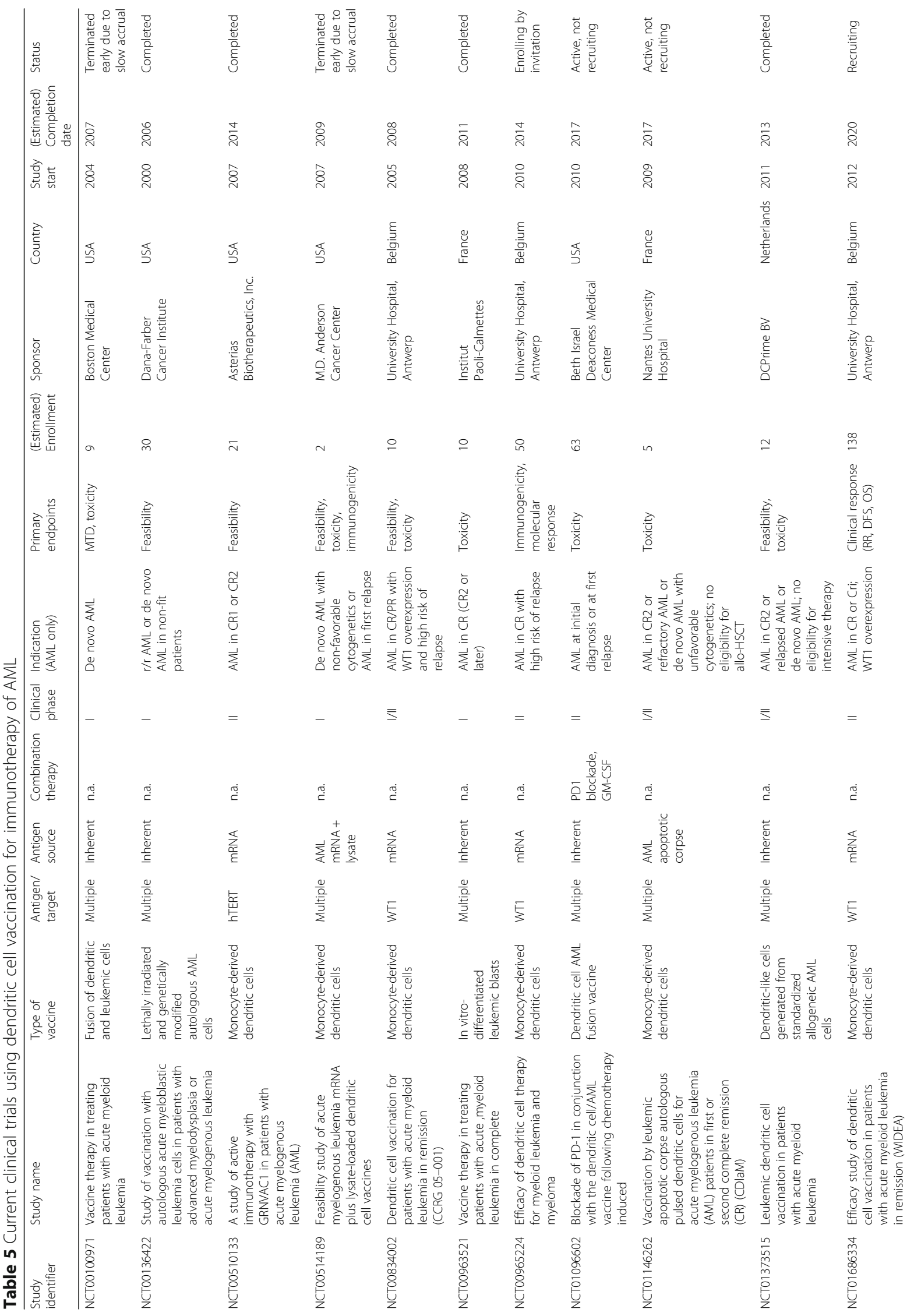




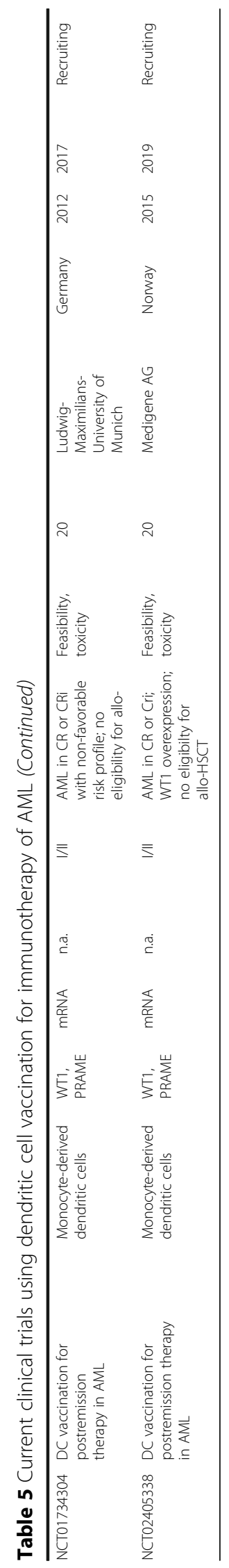




\section{Dendritic cell vaccination for immunotherapy of AML}

Vaccination strategies have the purpose to prime new or enhance pre-existing antigen-specific immune responses. DCs are highly eligible for the induction of tailored, strong, and durable responses (Fig. 1f). This is of particular importance for the treatment of tumor entities with low endogenous immune responses, such as AML. In spite of the high costs and efforts accruing for the production of this patient-specific cellular therapy, DCbased vaccination strategies for the treatment of AML are therefore actively pursued. Important variables in these studies are source of DC precursors, DC maturation protocol, target antigen, way of antigen loading route of application, and interval of application [100]. While monocyte-derived DCs are used in the majority of studies and are considered to induce the strongest immune responses, alternative DC-like constructs are also applied [1].

Recently, an interesting clinical trial has been published presenting 17 AML patients that were vaccinated in CR with a hybridoma of AML cells and autologous DCs [101]. The vaccination was well tolerated, and a considerable increase in leukemia-specific $\mathrm{T}$ cells was found that persisted for more than 6 months. High relapse-free survival was described, but a strong selection bias for long-term survivors currently impedes further interpretations. This patient cohort is part of a larger study that is designated to analyze the combinatorial effect of PD-1 blockade with the described vaccination strategy (NCT01096602, see Table 5). However, data for the combination therapy has not been released.

DCPrime uses an off-the-shelf product based on a precursor human dendritic cell line. This platform was tested in a phase I/II study for AML patients (NCT01373515), and vaccinations were well tolerated with induction of multi-functional immune responses, resulting in the preparation of a multi-center phase II study. However, there is no full publication of the study results available at present. To our knowledge, no other clinical trial is currently recruiting patients for vaccination concepts with DC-like cells, as a study based on a fusion concept has been terminated early due to slow accrual (NCT00100971), and two studies using modified leukemic blasts (NCT00136422, NCT00963521) have been completed, but their results have not been published (see Table 5).

Monocyte-derived DCs loaded with various antigens are the most commonly used source for DC vaccination trials. Five clinical studies are currently active or recruiting. A small French study $(n=5)$ uses AML apoptotic corpses to load DCs (NCT01146262). A group in Belgium that has already completed a phase I/II study on vaccination with WT1 mRNA-loaded DCs for 10 AML patients in remission with high risk of relapse demonstrating immunological as well as clinical responses [102] is now conducting a phase II study testing the induction of immune and molecular responses by vaccination with WT1 mRNA-loaded DCs for AML as well as chronic myeloid leukemia and multiple myeloma patients (NCT 00965224). Besides, the same group also conducts a large (estimated enrollment, 138 patients) randomized phase II study on AML patients in CR/CRi with WT1 overexpression with the goal to determine clinical effects of DC vaccination in terms of relapse rate, diseasefree survival, and overall survival (NCT01686334). Results of this study are eagerly awaited, but are not to be expected before 2020 .

Our group in Munich has developed a protocol for the generation of DCs by the use of a TLR7/8 agonist $[103,104]$. These DCs show improved immunogenicity compared to conventional monocyte-derived DCs [105]. We are currently conducting a phase I/II proof-of-concept study using this type of DCs loaded with mRNA encoding WT1 and PRAME for intradermal vaccination of AML patients in CR with a nonfavorable risk profile (NCT01734304) [106]. Preliminary results for 13 patients have already been reported at ASH, showing that DC generation is feasible, that their application is safe with delayed-type hypersensitivity reactions at the injection sites, but no serious adverse events, and that novel immune responses to both antigens can be induced. Immune responses were markedly increased by combination of DC vaccination with azacitidine within an individual treatment attempt [107]. A very similar study is conducted by our collaborators in Norway (NCT02405338).

Besides current clinical studies, a few interesting new developments in the field of DCs in the context of AML immunotherapy have been described in the past 2 years. In an effort to further optimize the immunostimulatory capacities of monocyte-derived DCs, electroporation of mRNA encoding both for IL-15 and for IL-15 receptor alpha was shown to result in enhanced NK cell activation [108]. Besides, evidence was provided that monocytederived DCs express RHAMM independent of RNA electroporation at a level high enough to induce RHAMM-specific T cells [109].

In conclusion, current data suggests that DC vaccination is particularly successful at inducing novel immune responses. Combining this approach with checkpoint inhibition or immunomodulating agents including HMAs in order to further enhance the immune responses seems an interesting way to follow.

\section{Conclusions}

Immunotherapy of cancer has made unprecedented progress in the past few years. While novel immunotherapeutic strategies have already moved into standard 
clinical practice for various solid cancers as well as selected hematological neoplasms including ALL, a similar development is lagging behind for the treatment of AML. However, different immunotherapeutic concepts are currently being evaluated in clinical trials, with some promising results already published and a lot more of interesting studies expected to be completed within the next couple of years.

The lack of an appropriate target antigen with a restricted expression pattern similar to CD19 or CD20 for $\mathrm{B}$ cell neoplasms is a major obstacle for the application of targeted immunotherapy in AML. This problem is shared by ADCs, T cell-recruiting antibody constructs and CAR T cell constructs, where promising leukemiaspecific responses seen in early clinical trials are often accompanied by severe on-target off-leukemia toxicity to the myeloid compartment. CD33 and CD123 are the major target antigens of constructs in clinical development so far. Results of the ongoing clinical trials need to be awaited in order to weigh potential benefits vs. side effects. In order to prospectively reduce on-target off-leukemia toxicities, several strategies are followed: The identification of novel leukemia-associated antigens could provide more specific targets. Comprehensive transcriptomic and proteomic analysis is ongoing to fully characterize the AML surfaceome [110]. Alternatively, leukemia-specific neoantigens arising from AML-associated mutations should be further evaluated as source of novel target molecules. Furthermore, dual-targeting approaches could improve treatment specificity while relying on combinations of already known AML-associated antigens.

ADCs have already proven their therapeutic potential in AML. Results of currently running clinical trials will help to identify the optimal clinical setting and to better estimate the risk-benefit ratio. In contrast, $\mathrm{T}$ cellrecruiting antibodies and CAR $\mathrm{T}$ cell constructs are still in the early phase of clinical development for the therapy of AML, with several currently running phase I trials studying the feasibility and toxicity of their application. Activation of endogenous $\mathrm{T}$ cell responses through checkpoint blockade and/or DC vaccines appears to be safe, but has yet to demonstrate its clinical potency when used as a monotherapy for the treatment of AML. Different combinations including HMAs to modulate immune responsiveness appear suitable and are increasingly being tested.

While immunotherapy in AML is complicated by different characteristics including lack of an AML-specific target antigen, low mutational burden resulting in low endogenous immune responses and intrinsic resistance mechanisms of the leukemic blasts against immune responses, remarkable progress has been made with different strategies in the past few years. Hope is high that alternative immunotherapeutic strategies with less treatment-related morbidity and mortality compared to allogeneic HSCT will move into clinical practice within the coming years. Still, many further steps have to be taken before the vision of an individualized immunotherapy for each AML patient based on risk factors and biomarkers can become clinical reality.

\begin{abstract}
Abbreviations
ADC: Antibody-drug conjugate; AE: Adverse event; ALL: Acute lymphoblastic leukemia; AML: Acute myeloid leukemia; BiTE: Bispecific T cell engager; CAR: Chimeric antigen receptor; CIK: Cytokine-induced killer; CMML: Chronic myelomonocytic leukemia; CR: Complete response; CRi: Complete remission with incomplete recovery; DART: Dual-affinity re-targeting; DC: Dendritic cell; FDA: Food and Drug Administration; GO: Gemtuzumab ozogamicin; HMA: Hypomethylating agent; HSCT: Hematopoietic stem cell transplantation; LIC: Leukemia-initiating cell; MDS: Myelodysplastic syndrome: NSG: NOD/SCID gamma null; ORR: Overall response rate; OS: Overall survival; $r / r$ : Relapsed or refractory; RCT: Randomized controlled trial; scFv: Singlechain variable fragment; VOD: Veno-occlusive disease
\end{abstract}

\section{Acknowledgements}

Not applicable.

\section{Funding}

The work was supported in part by funds from BaylmmuNet, the Bavarian Immunotherapy Network (http//www.bayimmunet.de), i-Target Immunotargeting of cancer (https://www.elitenetzwerk.bayern.de/doktorandenkollegs/doktorandenkollegs-nach-wissenschaftsbereichen/i-target), SFB1243 and the Helmholtz Alliance for Immunotherapy.

\section{Availability of data and materials}

Not applicable.

\section{Authors' contributions}

FSL and MS developed the concept for the article and revised the complete manuscript. FSL contributed the sections "Abstract", "Checkpoint inhibition",

"Dendritic cell vaccination", and "Conclusions". CK wrote the sections "Antibodydrug conjugates" and "T cell-engaging antibody constructs". SH authored the section about "CAR T cells". TK contributed to the different sections regarding combination strategies and created the figure. MS wrote the section

"Background". All authors read and approved the final manuscript.

Ethics approval and consent to participate

Not applicable.

Consent for publication

Not applicable.

Competing interests

MS received research funding from Amgen and Roche. MS received either travel reimbursements or consultant fees from Amgen, Celgene, Pfizer, and Seattle Genetics. All other authors declare that they have no competing interests.

\section{Publisher's Note}

Springer Nature remains neutral with regard to jurisdictional claims in published maps and institutional affiliations.

\section{Author details}

'Department of Medicine III, University Hospital, LMU Munich, Germany. 'Laboratory of Translational Cancer Immunology, Gene Center, Munich, Germany. ${ }^{3}$ German Cancer Consortium (DKTK), Partner Site, Munich, Germany. ${ }^{4}$ German Cancer Research Center (DKFZ), Heidelberg, Germany. 
Received: 18 March 2017 Accepted: 26 June 2017 Published online: 25 July 2017

\section{References}

1. Lichtenegger FS, Schnorfeil FM, Hiddemann W, Subklewe M. Current strategies in immunotherapy for acute myeloid leukemia. Immunotherapy. 2013;5(1):63-78

2. Lichtenegger FS, Krupka C, Köhnke T, Subklewe M. Immunotherapy for acute myeloid leukemia. Semin Hematol. 2015;52(3):207-14.

3. Cornelissen JJ, Gratwohl A, Schlenk RF, Sierra J, Bornhäuser M, Juliusson G, et al. The European LeukemiaNet AML Working Party consensus statement on allogeneic HSCT for patients with AML in remission: an integrated-risk adapted approach. Nat Rev Clin Oncol. 2012;9(10):579-90.

4. Stelljes M, Krug U, Beelen DW, Braess J, Sauerland MC, Heinecke A, et al. Allogeneic transplantation versus chemotherapy as postremission therapy for acute myeloid leukemia: a prospective matched pairs analysis. J Clin Oncol. 2014;32(4):288-96.

5. Ramos NR, Mo CC, Karp JE, Hourigan CS. Current approaches in the treatment of relapsed and refractory acute myeloid leukemia. J Clin Med. 2015:4(4):665-95.

6. Thomas DA, O'Brien S, Kantarjian HM. Monoclonal antibody therapy with rituximab for acute lymphoblastic leukemia. Hematol Oncol Clin North Am. 2009;23(5):949-71. v.

7. Kantarjian HM, DeAngelo DJ, Stelljes M, Martinelli G, Liedtke M, Stock W, et al. Inotuzumab ozogamicin versus standard therapy for acute lymphoblastic leukemia. N Engl J Med. 2016;375(8):740-53.

8. Aldoss I, Bargou RC, Nagorsen D, Friberg GR, Baeuerle PA, Forman SJ. Redirecting T cells to eradicate B-cell acute lymphoblastic leukemia: bispecific T-cell engagers and chimeric antigen receptors. Leukemia. 2017.

9. Topp MS, Gökbuget N, Stein AS, Zugmaier G, O'Brien S, Bargou RC, et al. Safety and activity of blinatumomab for adult patients with relapsed or refractory B-precursor acute lymphoblastic leukaemia: a multicentre, singlearm, phase 2 study. Lancet Oncol. 2015;16(1):57-66.

10. Holzinger A, Barden M, Abken $H$. The growing world of CAR T cell trials: a systematic review. Cancer Immunol Immunother. 2016;65(12):1433-50.

11. Rotiroti MC, Arcangeli S, Casucci M, Perriello V, Bondanza A, Biondi A, et al. Acute myeloid leukemia targeting by chimeric antigen receptor $T$ cells: bridging the gap from preclinical modeling to human studies. Hum Gene Ther. 2016.

12. Hoseini SS, Cheung NK. Acute myeloid leukemia targets for bispecific antibodies. Blood Cancer J. 2017;7(2), e522.

13. Hude I, Sasse S, Engert A, Bröckelmann PJ. The emerging role of immune checkpoint inhibition in malignant lymphoma. Haematologica. 2017;102(1): 30-42.

14. Peters C, Brown S. Antibody-drug conjugates as novel anti-cancer chemotherapeutics. Biosci Rep. 2015;35(4), e00225.

15. Bross PF, Beitz J, Chen G, Chen XH, Duffy E, Kieffer L, et al. Approval summary: gemtuzumab ozogamicin in relapsed acute myeloid leukemia. Clin Cancer Res. 2001;7(6):1490-6.

16. Petersdorf H, Kopecky J, Slovak M, Willman C, Nevill T, Brandwein J, et al. A phase III study of gemtuzumab ozogamicin during induction and postconsolidation therapy in younger patients with acute myeloid leukemia. Blood. 2013;121(24):4854-60.

17. Hills RK, Castaigne S, Appelbaum FR, Delaunay J, Petersdorf S, Othus M, et al. Addition of gemtuzumab ozogamicin to induction chemotherapy in adult patients with acute myeloid leukaemia: a meta-analysis of individual patient data from randomised controlled trials. Lancet Oncol. 2014;15(9):986-96.

18. Loke J, Khan JN, Wilson JS, Craddock C, Wheatley K. Mylotarg has potent antileukaemic effect: a systematic review and meta-analysis of anti-CD33 antibody treatment in acute myeloid leukaemia. Ann Hematol. 2015;94(3):361-73.

19. Amadori S, Suciu S, Selleslag D, Aversa F, Gaidano G, Musso M, et al. Gemtuzumab ozogamicin versus best supportive care in older patients with newly diagnosed acute myeloid leukemia unsuitable for intensive chemotherapy: results of the randomized phase III EORTC-GIMEMA AML-19 trial. J Clin Oncol. 2016:34(9):972-9.

20. Nand S, Othus M, Godwin JE, Willman CL, Norwood TH, Howard DS, et al. A phase 2 trial of azacitidine and gemtuzumab ozogamicin therapy in older patients with acute myeloid leukemia. Blood. 2013;122(20):3432-9.

21. Walter RB, Medeiros BC, Gardner KM, Orlowski KF, Gallegos L, Scott BL, et al. Gemtuzumab ozogamicin in combination with vorinostat and azacitidine in older patients with relapsed or refractory acute myeloid leukemia: a phase I/II study. Haematologica. 2014;99(1):54-9.

22. Daver N, Kantarjian H, Ravandi F, Estey E, Wang X, Garcia-Manero G, et al. A phase II study of decitabine and gemtuzumab ozogamicin in newly diagnosed and relapsed acute myeloid leukemia and high-risk myelodysplastic syndrome. Leukemia. 2016;30(2):268-73.

23. Nguyen DH, Ball ED, Varki A. Myeloid precursors and acute myeloid leukemia cells express multiple CD33-related Siglecs. Exp Hematol. 2006;34(6):728-35.

24. Ehninger A, Kramer M, Röllig C, Thiede C, Bornhäuser M, von Bonin M, et al. Distribution and levels of cell surface expression of CD33 and CD123 in acute myeloid leukemia. Blood Cancer J. 2014;4, e218.

25. Krupka C, Kufer P, Kischel R, Zugmaier G, Bögeholz J, Köhnke T, et al. CD33 target validation and sustained depletion of AML blasts in long-term cultures by the bispecific T-cell-engaging antibody AMG 330. Blood. 2014; 123(3):356-65.

26. McCombs JR, Owen SC. Antibody drug conjugates: design and selection of linker, payload and conjugation chemistry. AAPS J. 2015;17(2):339-51.

27. Linenberger ML. CD33-directed therapy with gemtuzumab ozogamicin in acute myeloid leukemia: progress in understanding cytotoxicity and potential mechanisms of drug resistance. Leukemia. 2005;19(2):176-82.

28. Kung Sutherland MS, Walter RB, Jeffrey SC, Burke PJ, Yu C, Kostner $\mathrm{H}$, et al. SGN-CD33A: a novel CD33-targeting antibody-drug conjugate using a pyrrolobenzodiazepine dimer is active in models of drug-resistant AML. Blood. 2013;122(8):1455-63.

29. Bixby DL, Stein AS, Fathi AT, Kovavsovics TJ, Levy MY, Erba HP, et al. Vadastuximab talirine monotherapy in older patients with treatment naive CD33-positive acute myeloid leukemia (AML). Blood. 2016;128:590.

30. Fathi AT, Erba HP, Lancet JE, Stein EM, Ravandi F, Faderl S, et al. Vadastuximab talirine plus hypomethylating agents: a well-tolerated regimen with high remission rate in frontline older patients with acute myeloid leukemia (AML). Blood. 2016;128:591.

31. Erba HP, Levy MY, Vasu S, Stein AS, Fathi AT, Maris MB, et al. A phase 1b study of vadastuximab talirine in combination with $7+3$ induction therapy for patients with newly diagnosed acute myeloid leukemia (AML). Blood. 2016;128:211.

32. Seattle Genetics, Inc. Seattle Genetics announces clinical hold on several phase 1 trials of vadastuximab talirine (SGN-CD33A). http://www.businesswire.com/ news/home/20161227005087/en/Seattle-Genetics-Announces-Clinical-HoldPhase-1. Accessed 6 Mar 2017.

33. Testa U, Pelosi E, Frankel A. CD 123 is a membrane biomarker and a therapeutic target in hematologic malignancies. Biomark Res. 2014;2(1):4.

34. Krystal WM, Walker R, Fishkin N, Audette C, Kovtun Y, Romanelli A. IMGN779, a CD33-targeted antibody-drug conjugate (ADC) with a novel DNAalkylating effector molecule, induces DNA damage, cell cycle arrest, and apoptosis in AML cells. Blood. 2015;126:1366.

35. Whiteman KR, Noordhuis $P$, Walker R, Watkins $K$, Kovtun $Y$, Harvey L, et al. The antibody-drug conjugate (ADC) IMGN779 is highly active in vitro and in vivo against acute myeloid leukemia (AML) with FLT3-ITD mutations. Blood. 2014;124:2321.

36. Portwood S, Puchalski RA, Walker RM, Wang ES. Combining IMGN779, a novel anti-CD33 antibody-drug conjugate (ADC), with the PARP inhibitor, olaparib, results in enhanced anti-tumor activity in preclinical acute myeloid leukemia (AML) models. Blood. 2016;128(22):1645.

37. Laszlo GS, Gudgeon CJ, Harrington KH, Dell'Aringa J, Newhall KJ, Means GD, et al. Cellular determinants for preclinical activity of a novel CD33/CD3 bispecific T-cell engager (BiTE) antibody, AMG 330, against human AML. Blood. 2014;123(4):554-61.

38. Borthakur G, Rosenblum MG, Talpaz M, Daver N, Ravandi F, Faderl S, et al. Phase 1 study of an anti-CD33 immunotoxin, humanized monoclonal antibody M195 conjugated to recombinant gelonin (HUM-195/rGEL), in patients with advanced myeloid malignancies. Haematologica. 2013;98(2):217-21.

39. Noordhuis P, Terwinjn M, Rutten AP, Smit L, Ossenkoppele GJ, Schuurhuis GJ. Targeting of CLEC12A in acute myeloid leukemia by antibody-drugconjugates and bispecific CLL-1 × CD3 BiTE antibody. Blood. 2010;116:2890.

40. Kim SY, Theunissen JW, Balibalos J, Liao-Chan S, Babcock MC, Wong T, et al. A novel antibody-drug conjugate targeting SAlL for the treatment of hematologic malignancies. Blood Cancer J. 2015;5, e316.

41. Buckley SA, Walter RB. Antigen-specific immunotherapies for acute myeloid leukemia. Hematology Am Soc Hematol Educ Program. 2015;2015(1):584-95.

42. Flynn MJ, van Berkel PH, Zammarchi F, Tyrer PC, Akarca AU, Janghra N, et al. Mechanistic and pharmacodynamic studies of adct-301, a pyrrolobenzodiazepine 
(PBD) dimer-containing antibody drug conjugate (ADC) targeting CD25expressing hematological malignancies. Blood. 2015;126:1559.

43. Rudra-Ganguly N, Lowe C, Virata C, Leavitt M, Jin L, Mendelsohn B, et al. AGS62P1, a novel anti-FLT3 antibody drug conjugate, employing site specific conjugation, demonstrates preclinical anti-tumor efficacy in AML tumor and patient derived xenografts. Blood. 2015;126:3806.

44. Baeuerle PA, Reinhardt C. Bispecific T-cell engaging antibodies for cancer therapy. Cancer Res. 2009;69(12):4941-4.

45. Kontermann RE, Brinkmann U. Bispecific antibodies. Drug Discov Today. 2015;20(7):838-47.

46. Kantarjian H, Stein A, Gökbuget N, Fielding AK, Schuh AC, Ribera JM, et al. Blinatumomab versus chemotherapy for advanced acute lymphoblastic leukemia. N Engl J Med. 2017;376(9):836-47.

47. Aigner M, Feulner J, Schaffer S, Kischel R, Kufer P, Schneider K, et al. T lymphocytes can be effectively recruited for ex vivo and in vivo lysis of AML blasts by a novel CD33/CD3-bispecific BiTE antibody construct. Leukemia. 2013;27(5):1107-15.

48. Krupka C, Kufer P, Kischel R, Zugmaier G, Lichtenegger FS, Köhnke T, et al. Blockade of the PD-1/PD-L1 axis augments lysis of AML cells by the CD33/ CD3-BiTE ${ }^{\bullet}$ antibody construct AMG 330: reversing a T-cell induced immune escape mechanism. Leukemia. 2015;30(2):484-91.

49. Arndt C, Feldmann A, von Bonin M, Cartellieri M, Ewen EM, Koristka S, et al. Costimulation improves the killing capability of $\mathrm{T}$ cells redirected to tumor cells expressing low levels of CD33: description of a novel modular targeting system. Leukemia. 2014;28(1):59-69.

50. Reusch U, Harrington KH, Gudgeon CJ, Fucek I, Ellwanger K, Weichel M, et al. Characterization of CD33/CD3 tetravalent bispecific tandem diabodies (TandAbs) for the treatment of acute myeloid leukemia. Clin Cancer Res. 2016;22(23):5829-38

51. Moore PA, Zhang W, Rainey GJ, Burke S, Li H, Huang L, et al. Application of dual affinity retargeting molecules to achieve optimal redirected T-cell killing of B-cell lymphoma. Blood. 2011;117(17):4542-51.

52. Rader C. DARTs take aim at BiTEs. Blood. 2011;117(17):4403-4.

53. AL Hussaini MH, Ritchey J, Rettig MP, Eissenberg L, Uy GL, Chichili G, et al. Targeting CD123 in leukemic stem cells using dual affinity re-targeting molecules (DARTs ${ }^{\oplus}$ ) [abstract]. Blood. 2013;122(21):360.

54. Chichili GR, Huang L, Li H, Burke S, He L, Tang Q, et al. A CD3xCD123 bispecific DART for redirecting host $T$ cells to myelogenous leukemia: preclinical activity and safety in nonhuman primates. Sci Transl Med. 2015;7(289):289ra82.

55. Chu SY, Pong E, Chen H, Phung S, Chan EW, Endo NA, et al. Immunotherapy with long-lived anti-CD123 $\times$ anti-CD3 bispecific antibodies stimulates potent T cell-mediated killing of human AML cell lines and of CD123+ cells in monkeys: a potential therapy for acute myelogenous leukemia. Blood. 2014;124:2316.

56. Forslund A, Syed K, Axel A, McDaid R, Li Y, Ballesteros J, et al. Ex vivo activity profile of the CD123xCD3 Duobody ${ }^{\otimes}$ antibody JNJ-63709178 against primary acute myeloid leukemia bone marrow samples. Blood. 2016;128:2875.

57. Gaudet F, Nemeth JF, McDaid R, Li Y, Harman B, Millar H, et al. Development of a CD123xCD3 bispecific antibody (JNJ-63709178) for the treatment of acute myeloid leukemia (AML). Blood. 2016;128:2824.

58. Bakker ABH, Oudenrijn SVD, Bakker AQ, Feller N, Meijer MV, Bia JA, et al. Ctype lectin-like molecule-1: a novel myeloid cell surface marker associated with acute myeloid leukemia. Cancer Res. 2004;64(22):8443-50.

59. Rhenen AV, Dongen GAMSV, Kelder A, Rombouts EJ, Feller N, Moshaver $B$, et al. The novel AML stem cell-associated antigen CLL-1 aids in discrimination between normal and leukemic stem cells. Blood. 2007; 110(7):2659-66.

60. Van Loo PF, Doornbos R, Dolstra H, Shamsili S, Bakker L. Preclinical evaluation of MCLA117, a CLEC12AxCD3 bispecific antibody efficiently targeting a novel leukemic stem cell associated antigen in AML. Blood. 2015;126:325.

61. Roskopf CC, Braciak TA, Fenn NC, Kobold S, Fey GH, Hopfner KP, et al. Dualtargeting triplebody 33-3-19 mediates selective lysis of biphenotypic CD19+ CD33+ leukemia cells. Oncotarget. 2016;7(16):22579-89.

62. Polu KR, Lowman HB. Probody therapeutics for targeting antibodies to diseased tissue. Expert Opin Biol Ther. 2014;14(8):1049-53.

63. LaPorte SL, Hostetter DR, Wong L, Razo J, Diep L, White CW, et al. CD3-EGFR bispecific Probody ${ }^{\mathrm{TM}}$ therapeutics induced tumor regressions and increased therapeutic window in preclinical studies. Proceedings of the AACR-NCIEORTC International Conference: Molecular Targets and Cancer Therapeutics. 2015;14:Abstract nr A203.
64. Zugmaier G, Klinger M, Schmidt M, Subklewe M. Clinical overview of antiCD19 BiTE $\left(^{\oplus}\right)$ and ex vivo data from anti-CD33 BiTE $\left({ }^{\bullet}\right)$ as examples for retargeting T cells in hematologic malignancies. Mol Immunol. 2015.

65. Köhnke T, Krupka C, Tischer J, Knösel T, Subklewe M. Increase of PD-L1 expressing B-precursor ALL cells in a patient resistant to the CD19/CD3bispecific T cell engager antibody blinatumomab. J Hematol Oncol. 2015;8:111.

66. Gross G, Waks T, Eshhar Z. Expression of immunoglobulin-T-cell receptor chimeric molecules as functional receptors with antibody-type specificity. Proc Natl Acad Sci U S A. 1989;86(24):10024-8.

67. Finney HM, Lawson AD, Bebbington CR, Weir AN. Chimeric receptors providing both primary and costimulatory signaling in $\mathrm{T}$ cells from a single gene product. J Immunol. 1998;161(6):2791-7.

68. Turtle CJ, Hanafi LA, Berger C, Gooley TA, Cherian S, Hudecek M, et al. CD19 CAR-T cells of defined CD4+:CD8+ composition in adult B cell ALL patients. J Clin Invest. 2016;126(6):2123-38.

69. Locke FL, Neelapu SS, Bartlett NL, Siddiqi T, Chavez JC, Hosing CM, et al. Phase 1 results of ZUMA-1: a multicenter study of KTE-C19 antiCD19 CAR T cell therapy in refractory aggressive lymphoma. Mol Ther. 2017:25(1):285-95.

70. O'Leary M. FDA pilot project to develop a clinical database to examine safety in trials using CAR T-cells. http://www.ema.europa.eu/docs/en_GB/document_ library/Presentation/2016/12/WC500217505.pdf. Accessed 6 Mar 2017.

71. Juno Therapeutics, Inc. Juno Therapeutics reports fourth quarter and 2016 financial results. http://ir.junotherapeutics.com/phoenix.zhtml?c=253828\&p= irol-newsArticle_Print\&ID=2250772. Accessed 6 Mar 2017.

72. Porter DL, Hwang WT, Frey NV, Lacey SF, Shaw PA, Loren AW, et al. Chimeric antigen receptor $T$ cells persist and induce sustained remissions in relapsed refractory chronic lymphocytic leukemia. Sci Transl Med. 2015; 7(303):303ra139.

73. Chevallier P, Robillard N, Ayari S, Guillaume T, Delaunay J, Mechinaud F, et al. Persistence of CD33 expression at relapse in CD33(+) acute myeloid leukaemia patients after receiving gemtuzumab in the course of the disease. Br J Haematol. 2008;143(5):744-6.

74. O'Hear C, Heiber JF, Schubert I, Fey G, Geiger TL. Anti-CD33 chimeric antigen receptor targeting of acute myeloid leukemia. Haematologica. 2015; 100(3):336-44.

75. Kenderian SS, Ruella M, Shestova O, Klichinsky M, Aikawa V, Morrissette JJ, et al. CD33-specific chimeric antigen receptor $\mathrm{T}$ cells exhibit potent preclinical activity against human acute myeloid leukemia. Leukemia. 2015;29(8):1637-47.

76. Mardiros A, Dos Santos C, McDonald T, Brown CE, Wang X, Budde LE, et al. $T$ cells expressing CD123-specific chimeric antigen receptors exhibit specific cytolytic effector functions and anti-tumor effects against human acute myeloid leukemia. Blood. 2013;122(18):3138-48.

77. Tettamanti S, Marin V, Pizzitola I, Magnani CF, Giordano Attianese GM, Cribioli E, et al. Targeting of acute myeloid leukaemia by cytokine-induced killer cells redirected with a novel CD123-specific chimeric antigen receptor. Br J Haematol. 2013;161(3):389-401.

78. Pizzitola I, Anjos-Afonso F, Rouault-Pierre K, Lassailly F, Tettamanti S, Spinelli $\mathrm{O}$, et al. Chimeric antigen receptors against CD33/CD123 antigens efficiently target primary acute myeloid leukemia cells in vivo. Leukemia. 2014;28(8): 1596-605.

79. Thokala R, Olivares S, Mi T, Maiti S, Deniger D, Huls H, et al. Redirecting specificity of T cells using the sleeping beauty system to express chimeric antigen receptors by mix-and-matching of $\mathrm{VL}$ and $\mathrm{VH}$ domains targeting CD123+ tumors. PLoS One. 2016;11(8), e0159477.

80. Gill S, Tasian SK, Ruella M, Shestova O, Li Y, Porter DL, et al. Preclinical targeting of human acute myeloid leukemia and myeloablation using chimeric antigen receptor-modified T cells. Blood. 2014;123(15):2343-54.

81. Casucci M, di Nicolis Robilant B, Falcone L, Camisa B, Norelli M, Genovese P, et al. CD44v6-targeted T cells mediate potent antitumor effects against acute myeloid leukemia and multiple myeloma. Blood. 2013;122(20):3461.

82. Kenderian SS, Ruella M, Shestova O, Klichinsky M, Kim MY, Soderquist C, et al. Leukemia stem cells are characterized by CLEC12A expression and chemotherapy refractoriness that can be overcome by targeting with chimeric antigen receptor T cells. Blood. 2016;128:766.

83. Chien CD, Sauter CT, Ishii K, Nguyen SM, Shen F, Tasian SK, et al. Preclinical development of FLT3-redirected chimeric antigen receptor T cell immunotherapy for acute myeloid leukemia. Blood. 2016;128:1072.

84. Lynn RC, Feng Y, Schutsky K, Poussin M, Kalota A, Dimitrov DS, et al. Highaffinity FRB-specific CAR T cells eradicate AML and normal myeloid lineage without HSC toxicity. Leukemia. 2016;30(6):1355-64. 
85. Peinert S, Prince HM, Guru PM, Kershaw MH, Smyth MJ, Trapani JA, et al. Genemodified T cells as immunotherapy for multiple myeloma and acute myeloid leukemia expressing the Lewis Y antigen. Gene Ther. 2010;17(5):678-86.

86. Chang YH, Connolly J, Shimasaki N, Mimura K, Kono K, Campana D. A chimeric receptor with NKG2D specificity enhances natural killer cell activation and killing of tumor cells. Cancer Res. 2013;73(6):1777-86.

87. Ma Q, Garber HR, Lu S, He H, Tallis E, Ding X, et al. A novel TCR-like CAR with specificity for PR1/HLA-A2 effectively targets myeloid leukemia in vitro when expressed in human adult peripheral blood and cord blood T cells. Cytotherapy. 2016;18(8):985-94.

88. Ritchie DS, Neeson PJ, Khot A, Peinert S, Tai T, Tainton K, et al. Persistence and efficacy of second generation CAR T cell against the LeY antigen in acute myeloid leukemia. Mol Ther. 2013;21(11):2122-9.

89. Wang QS, Wang Y, Lv HY, Han QW, Fan H, Guo B, et al. Treatment of CD33directed chimeric antigen receptor-modified T cells in one patient with relapsed and refractory acute myeloid leukemia. Mol Ther. 2014;23(1):184-91.

90. Guzman ML, Sugita M, Zong H, Ewing-Crystal N, Trujillo-Alonso V, MenciaTrinchant N, et al. Allogeneic Tcra/ $\beta$ deficient CAR T-cells targeting CD123 prolong overall survival of AML patient-derived xenografts. Blood. 2016; 128(22):765.

91. Lanitis E, Poussin M, Klattenhoff AW, Song D, Sandaltzopoulos R, June CH, et al. Chimeric antigen receptor T cells with dissociated signaling domains exhibit focused antitumor activity with reduced potential for toxicity in vivo. Cancer Immunol Res. 2013;1(1):43-53.

92. Zah E, Lin MY, Silva-Benedict A, Jensen MC, Chen YY. T cells expressing CD19/CD20 bispecific chimeric antigen receptors prevent antigen escape by malignant B cells. Cancer Immunol Res. 2016;4(6):498-508.

93. Arndt C, Feldmann A, Koristka S, Cartellieri M, von Bonin M, Ehninger A, et al. Improved killing of AML blasts by dual-targeting of CD123 and CD33 via UniTARG a novel antibody-based modular T cell retargeting system. Blood. 2015;126:2565

94. Arcangeli S, Bardelli M, Tettamanti S, Rotiroti MC, Simonelli L, Magnani CF, et al. Unraveling the efficacy and safety profiles of anti-CD123 chimeric antigen receptors (CARs) in a model of acute myeloid leukemia immunotherapy by investigating CAR binding affinity and density variables. Blood. 2015;126:1359.

95. Resetca D, Neschadim A, Medin JA. Engineering hematopoietic cells for cancer immunotherapy: strategies to address safety and toxicity concerns. J Immunother. 2016;39(7):249-59.

96. Alatrash G, Daver N, Mittendorf EA. Targeting immune checkpoints in hematologic malignancies. Pharmacol Rev. 2016;68(4):1014-25.

97. Berger R, Rotem-Yehudar R, Slama G, Landes S, Kneller A, Leiba M, et al. Phase I safety and pharmacokinetic study of CT-011, a humanized antibody interacting with PD-1, in patients with advanced hematologic malignancies. Clin Cancer Res. 2008;14(10):3044-51.

98. Yang H, Bueso-Ramos C, DiNardo C, Estecio MR, Davanlou M, Geng QR, et al. Expression of PD-L1, PD-L2, PD-1 and CTLA4 in myelodysplastic syndromes is enhanced by treatment with hypomethylating agents. Leukemia. 2014:28(6):1280-8.

99. Daver N, Basu S, Garcia-Manero G, Cortes JE, Ravandi F, Jabbour EJ, et al. Phase IB/II study of nivolumab in combination with azacytidine (AZA) in patients (pts) with relapsed acute myeloid leukemia (AML). Blood. 2016; 128(22):763.

100. Sabado RL, Balan S, Bhardwaj N. Dendritic cell-based immunotherapy. Cell Res. 2017;27(1):74-95.

101. Rosenblatt J, Stone RM, Uhl L, Neuberg D, Joyce R, Levine JD, et al. Individualized vaccination of AML patients in remission is associated with induction of antileukemia immunity and prolonged remissions. Sci Transl Med. 2016;8(368):368ra171.

102. Van Tendeloo VF, Van de Velde A, Van Driessche A, Cools N, Anguille S, Ladell K, et al. Induction of complete and molecular remissions in acute myeloid leukemia by Wilms' tumor 1 antigen-targeted dendritic cell vaccination. Proc Natl Acad Sci U S A. 2010;107(31):13824-9.

103. Spranger S, Javorovic M, Bürdek M, Wilde S, Mosetter B, Tippmer S, et al. Generation of Th1-polarizing dendritic cells using the TLR7/8 agonist CL075. J Immunol. 2010;185(1):738-47.

104. Beck B, Dörfel D, Lichtenegger FS, Geiger C, Lindner L, Merk M, et al. Effects of TLR agonists on maturation and function of 3-day dendritic cells from AML patients in complete remission. J Transl Med. 2011;9:151.

105. Lichtenegger FS, Mueller K, Otte B, Beck B, Hiddemann W, Schendel DJ, et al. CD86 and IL-12p70 are key players for T helper 1 polarization and natural killer cell activation by toll-like receptor-induced dendritic cells. PLoS One. 2012;7(9), e44266.

106. Subklewe M, Geiger C, Lichtenegger FS, Javorovic M, Kvalheim G, Schendel DJ, et al. New generation dendritic cell vaccine for immunotherapy of acute myeloid leukemia. Cancer Immunol Immunother. 2014;63(10):1093-103.

107. Lichtenegger FS, Deiser K, Rothe M, Schnorfeil FM, Krupka C, Augsberger C, et al. Induction of antigen-specific T-cell responses through dendritic cell vaccination in AML: results of a phase I/II trial and ex vivo enhancement by checkpoint blockade. Blood. 2016;128(22):764.

108. Van den Bergh J, Willemen Y, Lion E, Van Acker H, De Reu H, Anguille S, et al. Transpresentation of interleukin-15 by IL-15/IL-15Ra mRNA-engineered human dendritic cells boosts antitumoral natural killer cell activity. Oncotarget. 2015;6(42):44123-33.

109. Willemen Y, Van den Bergh JM, Bonte SM, Anguille S, Heirman C, Stein BM, et al. The tumor-associated antigen RHAMM (HMMR/CD168) is expressed by monocyte-derived dendritic cells and presented to T cells. Oncotarget. 2016;7(45):73960-70.

110. Perna F, Berman S, Mansilla-Soto J, Hamieh M, Juthani R, Soni R, et al. Probing the AML surfaceome for chimeric antigen receptor (CAR) targets. Blood. 2016:128(22):526.

\section{Submit your next manuscript to BioMed Central and we will help you at every step:}

- We accept pre-submission inquiries

- Our selector tool helps you to find the most relevant journal

- We provide round the clock customer support

- Convenient online submission

- Thorough peer review

- Inclusion in PubMed and all major indexing services

- Maximum visibility for your research

Submit your manuscript at www.biomedcentral.com/submit
Biomed Central 